DOI:

Веденеев Артем Рудольфович, протоиерей Русской православной иеркви (Пермская епархия) «ОТЦА АРЕСТОВАЛИ В МОЙ ДЕНЬ РОЖДЕНИЯ...»¹

Аннотация. Рассказывается история семьи автора, приводятся вспоминания о детстве и об отце - известном художнике, скульпторе Рудольфе Борисовиче Веденееве. Эти воспоминания содержат информацию и об облике Перми второй половины XX в., и эпизоды из жизни семьи, рассказанные автору родственниками, и, наконец, его личные воспоминания. В этой семейной истории находят отражение события, которые затронули большую часть населения тогда ещё Советского Союза. Это и Великая Отечественная война, и быт послевоенного времени, и репрессии, и преследование инакомыслия.

Ключевые слова: история семьи, воспоминания, повседневность, Пермь, XX в.

Vedeneev Artem Rudolfovich, Archpriest of the Russian Orthodox Church

\title{
"THE FATHER WAS ARRESTED ON MY BIRTHDAY ..."
}

Annotation. The author tells about the history of his family, recalls his childhood and his father, who was a famous artist, sculptor Rudolf Borisovich Vedeneev. These memoirs contain information about the appearance of Perm in the second half of the twentieth century, and episodes from the life of the family, told to the author by relatives, and, finally, his personal memories. This family history reflects the events that affected most of the population of the Soviet Union at that time. This is the Great Patriotic War, and the life of the post-war period, and repression, and the persecution of dissidence.

Keywords: family history, memories, everyday life, Perm, XX century.

В.В. Дегтярников: Дорогие друзья, мы начинаем одну из серии лекций «Культурно-воспитательной части». Сегодня у нас в гостях протоиерей Артемий Веденеев, и лекция протоиерея будет

1 Запись публичной лекции, прочитанной 02.12.2020 г. в в Пермской краевой библиотеке им. А.М. Горького. 
посвящена истории его семьи, фактически, истории его отца, Рудольфа Веденеева, известного художника, скульптора. И я попрошу Вас, батюшка, начинать.

А.Р. Веденеев: Сейчас для того чтобы определить, где находился наш дом, надо от угла школы №17 отсчитать три тополя, между третьим и четвертым тополем находились ворота в наш двор, проезд. Соответственно, начиная с четвёртого тополя, в сторону 35-го двора, которого сейчас тоже нет, в сторону ЦУМа, вот как раз наш дом находился. Вообще, примечательно, что после того как наша квартира, квартира над нами и рядом с нами были признаны аварийными, потому что угол, можно сказать так, моей комнаты, выпадывал, а в стене, где было окно, была такая трещина, что улицу было видно. Так вот, после того, как мы оттуда переехали, через какое-то время стали расселять весь дом. Весь дом переехал, и оказалось, что только в одном окне горит свет. Оказалось, что в нашей аварийной квартире живёт одинокая женщина, которая к нам никакого отношения не имела и родственником нашим не являлась. Но вот примечательно, можно сказать, что мы как некий последний форпост дома № 33. В начале, как отец рассказывал, до начала Великой Отечественной войны, извините за повтор, семья жила на втором этаже. Это купеческий дом, и окна большие на втором этаже, вот это, скорее всего, наши окна. А вот в этом месте, вот видите, две калиточки, сидел сапожник. Я готов предположить, что где-то вот здесь семья отца жила. Значит, старший брат отца, Рэм [Арнольд Борисович Веденеев], [19]35-го года рождения, сам папа [19]39-го, их младшая сестра, соответственно моя тётя Инна, она вообще родилась перед Великой Отечественной войной. И вот где-то ближе к весне 1941 г. было решено, что в начале лета семья поедет сначала к родителям мужа, то есть моего деда, Бориса Петровича, в Ленинград, а потом уже оттуда поедут на родину бабушки, под Вышний Волочок. В общем хотели показать всех детей. Уже билеты были взяты, но получилось так, что вначале уезжала бабушка, Любовь Семёновна, со старшим Рэмом, средним Рудольфом [и младшей Инной], то есть с тремя детьми на руках. Сели они на Перми-II и поехали. Договоренность была такая, что отец, ну дед в данном случае, Борис Петрович, потом сам приедет и догонит их в Ленинграде. Но когда бабушка приехала в июне 1941 г. в Ленинград, выяснилось, что с работы 
деда не отпускают, несмотря на то, что, повторюсь, билеты были на руках. Да и вообще, дед был не последним специалистом в трамвайном депо, поскольку в 1935 г. ему подарили подписной именной специального заказа чернильный набор, он сохранился у нас в семье. Такой вот, две чернильницы, подставка для ручки и написано «Веденееву Борису Петровичу от работников за ударный труд». Вышло так, что деда, Бориса Петровича, призвали, и его никто не провожал, поскольку бабушка была в Ленинграде в тот момент. Какое-то время им можно было ещё пожить в Ленинграде, недолго, недели две-три от силы. И бабушка решила, что пока поезда ходят, надо доехать к её родителям. В общем, представляете, с тремя детьми, да ещё с какими-то пожитками, а Инна-то вообще же маленький ребёнок, приехала к своим родителям. И уже известно, что началась война. Эту зиму первую они как-то там перемогались, было достаточно непросто, я бы так сказал. Хотя понятно, что жили в деревне, какие-то запасы были. Тем более дед наш, ну то есть прадед, был кузнец, то есть всегда востребован. Ну и какие-то ещё может быть были с собой проездные документы, позволяющие хоть где-то что-то приобретать. Весной 1942 г. пришла похоронка на деда: «Настоящим сообщаем, что ваш муж, Веденеев Борис Петрович, верный присяге, погиб смертью храбрых». Тогда уже стало ясно, что вторую зиму уже так не пережить. И как это ни прискорбно звучит, сам факт наличия официальной бумаги, он каким-то образом позволил семье выжить. Потому что дедушка погиб в боях под Ржевом, вот в тех местах, где сейчас памятник стоит, вы знаете. И если бы он пропал без вести, по реалиям того времени, семья не получила бы ничего, то есть просто ничего. И хуже того, стали бы социальными изгоями. Представляете, что такое во время войны пропавший без вести? Это всё равно, что в изменники тебя записывают. А так, пришлось бабушке брать детей, какие-то продукты родители насобирали им в дорогу и на какой-то там, скорее всего, полуторке, вместе со своими «товарками», как тогда говорили, то есть с такими же женщинами, у которых в общем дети на руках, они поехали на железнодорожную станцию. И вдруг по дороге попали под обстрел. Отец, кстати, потом вспоминал этот звук, нагнетаемый самолётом, который, по сути, приближается к земле, чтобы расстрелять. Все пожитки брошены, разбегаются все в разные стороны. Самолёт отстрелялся, 
улетел, и начинают всех обратно собирать. Ну, вот тут вот, как я понимаю, папа рассказывал уже со слов бабушки, что уже все там собрали какие-то свои пожитки, залезают обратно наверх, а отца нет. Не могут найти. Вот уже Рэма нашли, ну Инна понятно у бабушки на руках, а отца нет. Товарки начинают бабушку торопить, ну мало ли, может немец пострелял, убил мальчонку, жалко конечно. И тут бабушка им говорит, что я пока его не найду, я никуда не уеду. И бабушка принялась его искать. А оказывается, во время налёта, тогда было отцу почти 4 года, меньше даже, отец забился в поленницу, испугался. В том числе и от шока, тут взрослому-то человеку хватало, чтобы испугаться. Бабушка его зовёт, а отец не может ей ответить.

Ну, слава богу, нашёлся, и вот вернулись вновь в город Пермь. Попытались в этот наш дом прийти, а оказалось - квартира занята, уже год прошёл. Мало того, что квартира занята, почти все вещи, связанные в узлы простынею покидали в наш дровяник. Ну что там с ними стало за год. А всю остальную мебель, которая там чудом могла сохраниться, её пожгли, дрова ведь нужны, зима. И в результате единственную выделили комнатушку в этом же доме, со двора, дореволюционная постройка, так называемая летняя кухня. То есть одна стена-то ещё ничего, а вот вторая, как впоследствии, в общем, выяснилось, никуда не годится. И вот в этой маленькой комнатушке, в которой потом ваш покорный слуга тоже жил, жила бабушка с тремя детьми. Слава богу, в этой комнате была печка и одно окно. Я вот, сколько себя помню, у нас каждую весну сирень буйно цвела, да так, что света белого не видно. Но, может, это какое-то такое утешение было своеобразное. Кроме нашей комнаты, которая было прямо, была ещё одна, которая перпендикулярно размещалась. Там жила ещё одна семья, нам, конечно, не родня. Мне было лет 5, может быть чуть старше, у них была девочка, дочь, которая может и была меня старше, но не намного, на полгода, может месяцев на семь. И вот что-то с ней произошло. Я помню, дверь так полуоткрыта, взрослые что-то сдержанно говорят, и было понятно, что ребёнок умирает. Это к тому, чтобы был понятно, откуда у нас вторая комната появилась. Девочка умирает, и через какое-то короткое время эта осиротевшая семья уезжает. Вот эту комнату с промерзающим углом отдали нам. 
Раз уж про квартиру заговорил, чтобы ситуация по ней была понятна. У нас среди сохранившихся книг есть небольшой такой Устав ВКП (б) 1929 г.р. Да-да-да, вообее чудом сохранившийся раритет. Причём он подписан, карандашом написано: «Чуркин». Я думаю, что, скорее всего, откуда к нам ещё мог попасть устав ВКП (б), это подарок нашего соседа, который жил на первом этаже, дяди Вадика Чуркина. Дядя Вадик проходил свидетелем по Пермскому делу, он и его жена, тётя Валя. После того как мы уже переехали, а мы с дядей Вадиком переехали в один дом, он мне как-то говорит: «А вот знаешь, квартиру-то вашу ведь слушали». Я говорю: «Как так, дядя Вадик?». Он говорит: «А вот так. Человек, который над вами жил, к нему в комнату приходили люди из КГБ и, уж не знаю, какой там аппаратурой, прослушивали всю квартиру». Ну, это немудрено, деревянные же перекрытия. Ещё раз повторюсь, это летняя кухня, там ничего капитального не было, за исключением одной стены.

А квартира, которая была над нами, уникальная, я бы сказал, овеянная многими трагическими легендами. Отец рассказывал мне, что когда они приехали и стали жить постоянно в этом доме, из этой большой комнаты был виден дровяник. Дровяник этот был необыкновенен тем, что в три ряда весь был опоясан цепями, может быть, с мизинчик толщиной. Оказывается, был такой период, во время войны, до года может 45-го или 46-го, над нами в этой квартире жил какой-то мужчина, который занимал какую-то должность на некоем продуктовом складе. Ну, можете себе представить, что там творилось. Весь двор был в курсе, что он привозит и когда. Выглядело это так, подъезжала машина вплотную к дровянику, туда заносились какие-то коробочки, ящички, мешочки, потом это всё закрывалось на замок. А хозяин за сохранностью всего этого наблюдал со своего окна. У нас было одно окно, а наверху было двойное. Но наблюдение это ему особо не помогло, новость эта стала достоянием всей округи. Как потом выяснилось, хозяин стал понимать, что он привозит свои запасы, а они убывают. Вот он привезёт, а они не увеличиваются. А вокруг этого дровяника же, как муравейник, все налепили, кто что хотел. Ничего лучше он не придумал, как раздобыть где-то ружьё и охранять своё утащенное добро прямо внутри дровяника. Закончилось всё скорбно, в одну из ночей, уж не знаю, то ли он там задремал, то ли 
ещё как, отжали несколько досок из соседних дровяников. Условно, залезли в дровяник дяди Володи Палкина, а потом из дровяника дяди Володи Палкина в дровяник дяди Серёжи, а из дровяника дяди Серёжи уже сюда. Они его зарезали там, представляете, прямо внутри. То есть он ни охнуть, ни ахнуть, ни выстрелить не успел.

А потом подошло время, в конце войны папа пошёл в 21-ю школу, где было раздельное обучение, мальчишечьи классы отдельно, и девчоночьи отдельно. Как всякий нормальный человек, он сел на последнюю парту, на «камчатку», чтобы не вызывали. И вдруг оказалось, что в кои-то веки классная дама вызывает папу к доске и говорит ему, например, Веденеев, напиши. И пауза повисает. Как так? Вызывают бабушку в школу и спрашивают: «А вы ребёнком-то занимаетесь дома? Он делает домашнее задание?». Она отвечает: «Ну да, делает». На самом деле, ему брат старший помогал, Рэм. А учительница ей говорит: «Любовь Семёновна, так он у вас не видит же ничего». Оказалось, что все эти последствия переездов, войны, голода, они таким образом сказались. Видит, как в тумане. Повели к врачу, он сказал, что нужны очки. Я даже, честно говоря, не знаю, какое зрение у него с детства было. Но то, что по сути дела всю жизнь очки, это точно. То есть со второго класса. Во втором классе отцу пришлось пройти двойную программу, то есть программу первого и второго класса.

... Итак, со второго класса отец начал носить очки. Я его спрашиваю: «Папа, как ты в школе-то сидел?». Он говорит: «Я думал, так и надо, что все так видят, как я». Я говорю: «Ну как такто, ты же куда-то смотрел, на что-то ориентировался». Он говорит: «Так мы на что смотрели-то?». Я говорю: «Не знаю, на доску, или ещё куда-то». Он: «Да нет, на какую доску! На подоконник». Я спрашиваю: «А причём здесь подоконник-то?». Он говорит: «А притом. Дежурный в классе ходил в столовую школьную с ящиком. Этот ящик был разбит на ячейки, у каждой ячейки была написана фамилия, в эту ячейку дежурному повар выдавал пайку хлеба. Дежурный шёл в сопровождении. Приносил в класс, то есть все знали, что всем по кусочку хлеба лежит. Чтобы не было никаких недоразумений, дежурный клал этот ящичек на подоконник, а класс следил. Я говорю: «За кем следил-то?». Он говорит: «Да за крысами». Я говорю: «Как так, за крысами?». Он говорит: «Да так, крысы стали воровать наш хлеб, самые наглые заскакивали на по- 
доконник, хватали, что попало, и бежали. Мы же тоже, дети войны, неглупые же парни, и мы придумывали хлеб подвешивать». Я говорю: «Как это так? Куда его подвесишь-то?». А он говорит: «А у нас крюк для люстры был. Мы, придумали закинуть туда верёвку, на неё привязали наш ящичек с выдвижной крышкой, и подтянули к потолку. Ну и думаем, что на потолок крысы не залезут. Но тут, если бы я сам не видел, я бы не поверил. Наглые крысы способны залезть на потолок по абсолютно вертикальной стене. Ну и, естественно, весь класс подобного хамского отношения стерпеть не мог, и как только раздавался клич "шума" или “атас", весь класс хватал, что попало, как то пеналы, тетрадки, учебники, и начинал пулять по этим крысам наглым, которые хлеб воровали. Вот это мы видели, чего на доску-то смотреть».

Когда врачи подобрали очки отцу, он сам рассказывал, как будто вообще другой мир стал, и красочный, и яркий, и интересный. Наверное, с этих детских пор папа стал активно читать, и много всего перечитал. Нашёл несколько блокнотов, к сожалению, записи в них утеряны, так вообще впечатление такое, что не только Карла Маркса с Фридрихом Энгельсом, но и Ленина, и Каутского, и в общем много чего было перечитано. И причём не только перечитано, но и законспектировано, представляете себе. Я думаю, большая часть и книг, и тетрадок отца были изъяты во время Пермского дела и, может быть, потеряны навсегда. У нас стеллаж от пола до потолка, отец сам делал, всё было заставлено книгами, журналами, тетрадками, прямо до потолка. А потом уже, прямо скажем, места стало больше, потому что всё, что там стояло, всё исчезло.

Мама мне рассказывала, что как только я родился, папа пошёл и купил сто билетов в спортлото. Говорит, купили эту радиолу, «Эстония» она вроде называлась, которая очень хорошо ловила «Голос Америки» и «Немецкую волну», по-моему. Факт моего рождения, наверное, благосклонно был воспринят западными, чуждыми голосами, в этом смысле. Ну и разговоры такие были, что надо же заниматься мне, надо читать, писать, считать. И вот, когда мне исполнилось шесть лет, отец принёс большую, как мне тогда казалось, в детстве же всё большое, коробку, кубики, башенки такие. На нашем столе я целый город построил, со всякими переходами. Тогда было принято, что потенциальные первоклассники 
заранее должны как-то себя обозначить и записаться. Как-то так получилось, что из нашего 77-го детского сада чуть ли не вся группа, которая жила рядом, пошла в один класс. Перед тем как пойти в школу, поехали мы всей семьёй в деревню. Рано-рано утром, только-только рассветает, в бане дверь открыта, роса на траве, и вот слева, маленькое такое окошечко, и на нём стоит спелая жёлтая груша. Причём она стояла там каждое утро. Отец говорит: «Пока ты спал, зайчик приходил, принёс тебе грушу». И вот так почти каждый день было. Потом уже был август, мы поехали домой, потому что всё-таки надо в школу собираться. Мне купили новый ранец, такой серенький с лямочками, тетрадки. Если помните, были такие палочки для счёта, красные палочки, синие палочки. У меня даже азбука была, с буквами.

И вот 1 сентября собрались мы в школьном дворе. Тогда ведь многим ребятам, с которыми мы пошли в первый класс, не было официально семи лет. Например, вот у меня день рождения 11 сентября, то есть на 1 сентября мне ведь нет семи лет. А у Сани Двинянинова(?), который жил на Коммунистической, прямо рядом с детским садом, у того вообще 14 октября. И так у многих. Вот мы, прямо скажем, тогда все невысокого росточка, с букетами, с ранцами своими. Причём ранец же надо было сложить серьёзно, не так, что одна тетрадка, а с учебниками, то есть один учебник, второй, третий, чтобы выглядеть как нормальный ученик. Пошли мы в первый класс, нас там тогда строили. Причём так интересно, сейчас вход в 17-ю школу не через подвал, как раньше, а в уголочке. И вот взрослые, тогда десятиклассники, брали нас за ручки и вели по широкой лестнице, мне казалось, она такая большая и всё такое гигантское. Я пришёл недавно туда: потолки узкие, всё темно, думаю, вот что годы делают со школами.

Ну в общем, праздник жизни иногда имеет свойство меняться и заканчиваться. Мы узнали, что дело Пермское организовали. И как раз 11 сентября, мой день рождения, я же уже всё-таки первоклассник, у меня уже есть белая рубашка нарядная. Причём не только рубашка, мне сшили бабочку, как у папы. И вот мы сидим, ждём отца, который должен принести какие-то вкусности, подарки. Но не суждено было этому всему сбыться, то есть папа не пришёл. Вот университет родной, где отец учился на истфаке [демонстрирует слайд]. И вот в начале арестовали отца, мне по- 
чему-то кажется, что отец очень близко подошёл. Может быть квартал, между центральным гастрономом и улицей Газеты Звезда, примерно то место, где нельзя уйти проходными дворами. В этом квартале между [улищами] Сибирской (Карла Маркса бывшей) и Газеты Звезда нет ни одного проходного двора. А вот в нашем дворе можно было уйти проходными дворами чуть ли не до самой Камы, уйти куда хочешь, в общем. Вероятнее всего, где магазин (Табаки?), парикмахерская, напротив кинотеатра «Триумф», потому что на противоположной стороне можно было уйти проходными дворами на улицу Пушкина. Отца арестовали не только за чтение, но и распространение литературы, как это говорится «заведомо порочащей Советский строй». Ничего уже, конечно, не сохранилось, потому что всё, что было отпечатано, или через фотокопии, или через печатные машинки, у нас всё было изъято полностью, всё исчезло. Это вот статья, которая инкриминировалась Олегу Воробьёву, а это то, что отцу вменялось в вину [демонстрирует слайды].

В 1973 г., летом, после Кизеллага отец освобождается. И уже в октябре года срочно, на рысях, едем в город Владимир. Ну, ребёнок же никогда не видел города Владимира, надо ребёнку показать, храмы там, знаменитые ворота, музеи. Жили мы в гостинице «Владимир», а потом уже задним числом я узнал, что отец ездил на заседание к Олегу Воробьёву. Это как раз был достаточно переломный период, потому что Воробьёва после этого переведут сюда, в Пермь-36.

Дальше было ещё интереснее. В Ленинграде мы искали родню нашу. Дело в том, что история эта с дядей, это же реальный человек, ну, про которого отец рассказывал. У бабушки было два брата, вот один из них, Саша, всю жизнь занимавшийся спортом, здоровый такой. И вот он провожал свою девушку на поезд, и, как водится, сколько ни прощайся, всегда последних секунд не хватает. Он поднялся к ней в вагон, тут молодой чекист откуда-то появился, ну и достаточно по-хамски отозвался. Дядя ему сделал замечание. Он начал кричать, что он вообще не просто так тут, что он при исполнении, что он из органов [внутренних дел]. Ну, в общем, дядя его избил, набил ему морду. Дядю арестовали, он рассказывал, что он с бабушкой ходил его встречать на Пермь-II. Конечно, вернулся уже совсем другим человеком, инвалидом. Ещё не 
раздавленный, не сломленный, но инвалид. Так вот. А был ведь ещё один брат, который остался в Ленинграде. По моим некоторым отрывочным данным, один из потомков вот этой линии Веденеевых в Ленинградском театре оперы и балета был, вот искали их. Дядя Рэм был там с семьёй, мы там были, и папа потом ещё ездил. После войны, когда отец уже постарше был, ездил вот в те места, где дедушка погиб. И вот он рассказывал, как он с военруком местным говорил. Он заходит, говорит, вот такой-то... Он говорит: «По какому вопросу?» - «Ищу деда, который здесь погиб». Какие-то люди ходят и ходят, вдруг выходит военком и говорит: «Кто Веденеева отца ищет? Иди сюда». Отец заходит, закрывает дверь. И тот говорит ему: «Я воевал здесь. Если ты ищешь конкретно могилу отца, то, конечно, такую конкретную могилу ты не найдёшь, есть только братские могилы».

По-моему, через два года [после освобождения Р.Б. Веденеева], мы с отцом едем в Ленинград, примерно в этот же период туда ездил дядя Рэм, как он говорит, со своими девчонками. Понятно, что у нас там всё-таки родня, причём на нашей фамилии. Мне кажется, что вместе с этим какой-то там был человек, может быть два, который фактически стал «почтовым ящиком». Потому что спустя годы выяснилось, что между ними была какая-то связь. Причём не та, что принята между людьми, ментальная, а вполне конкретная, то есть они, может быть, переписывались, ну в общем, какое-то сообщение было. Потому что был один случай, очень малопонятный. Кажется мне, у кого-то возникло желание если не остановить отца, то припугнуть. Может быть, в архивах этого лечебного заведения что-то и сохранилось. Какой же это был год?.. В общем, как-то отец возвращался пешком с ВРЗ (вагоноремонтный завод). Мне тогда было девять лет, ездил на холодном трамвае со своими лыжами на жёстких креплениях, на валенках. И там, боюсь ошибиться на какой улице, вроде на Фонтанной, жил дядя Рэм, то есть брат отца. Что-то сподвигло отца ночью, правда, это было лето, идти домой. Ну, в общем закончилось всё скорбно, ктото на него напал и сломал челюсть. Отец лежал там, где памятник медсестре, какая там улица-то...За «Алмазом», там какие-то медицинские корпуса, вот в них он лежал. Сейчас, конечно, задним числом, не имея точных данных, остаётся только предполагать. Но вообще, отец физически очень сильный человек - все эти фигуры, 
скульптуры и отливки. Не могу назвать уж совсем сильным, но по тому, как он двигал их, понятно, что это всё было для него привычно. Когда отец рассказывал вообще об этом случае, мама у него стала спрашивать, как всё произошло. И он как-то сам собой не был доволен, ему сбили очки, пространство потерялось. У меня такое впечатление, конечно, не хочется быть буревестником, но почему-то это как-то связывается, скажем, так, с какими-то неформальными контактами отца, с тем же Воробьёвым. А почему я к этому склоняюсь: уже когда у отца была мастерская на перекрёстке улиц 25-го Октября и Луначарского, по-моему, в подвале, я у него как-то был. Какой это год... дай бог памяти, 1980-й какой-то... к нему пришёл какой-то молодой мужчина и у него такой огромный круглый значок. И на этом значке написано: «Спрашивайте, я член ДС» («Демократический Союз»).

Там была ещё одна девушка. Этот гость, который со значком, говорит: «Вы зачем тут бываете?». Я говорю: «Общаюсь». Он говорит: «Не надо вам с неформалами дружить, ни к чему хорошему это не приведёт». Проходит полгода, и оказывается, что этот носитель значка в Москве даёт пресс-конференцию, если вы знаете, о ком идёт речь, то поняли, хоть я никаких имён не называл... Я его видел один единственный раз в жизни, и фамилию сейчас не вспомню. Он даёт пресс-конференцию и говорит, что он внедрённый секретный сотрудник КГБ. Когда мне отец об этом говорит, я ему говорю: «Папа, откуда у тебя сей зелёный крокодил появился?». Он говорит: «Потому что я его знаю. На кого-то сослался, может на каких-то общих знакомых, ну пришёл и пришёл, чего выгонять..». Это всё к тому, что рассказ о том, что отца слушали в 68-м году не выглядит особо фантастичным, не выглядит, в моём понимании. [Демонстрирует слайд со скульптурой «Через человека» Р.Б. Веденеева] Попытался языком скульптуры показать, как можно перешагнуть через человека, какими бы внешне благовидными оправданиями это не прозвучало.

Если я что-то не рассказал, спрашивайте, а я что-нибудь отвечу. 


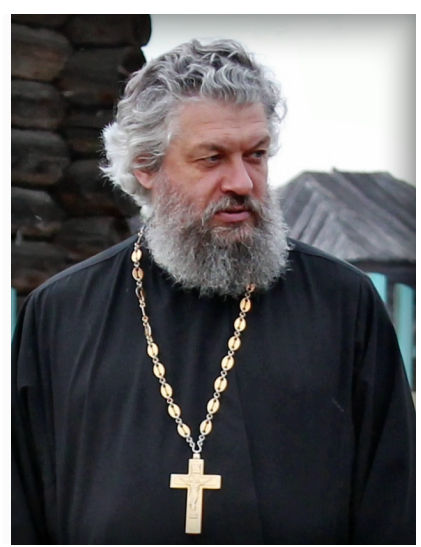

Гонтмахер Евгений

\section{Шлемович,}

доктор экономических наук, профессор Высшей школы экономики (Москва)

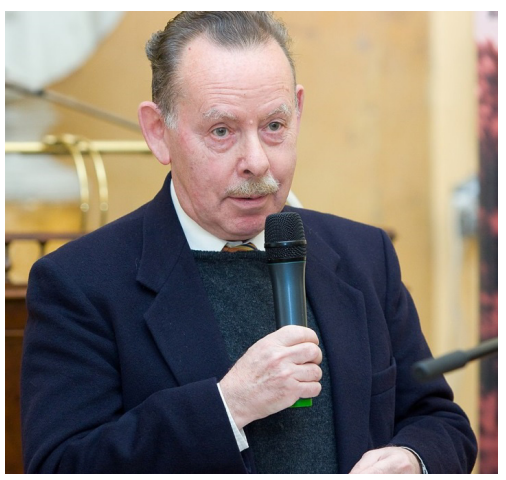

Веденеев Артем Рудольфович, протоиерей Русской православной церкви (Пермь)

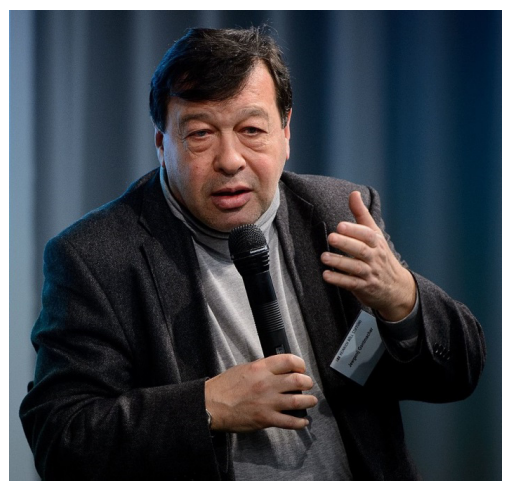

\section{Гордин Яков Аркадьевич,} редактор литературно-художественного, общественнополитического независимого журнала «Звезда»

(Санкт-Петербург) 
Дегтярева Мария Игоревна, доктор философских наук, кандидат исторических наук, Пермская епархия Русской православной церкви

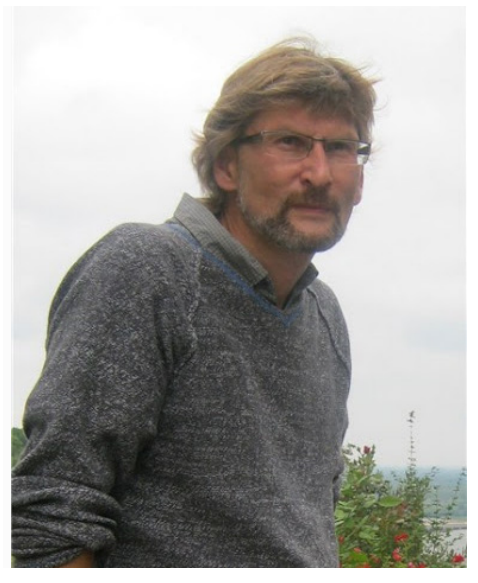

Измозик Владлен Семенович, доктор исторических наук, профессор Санкт-Петербургского государственного университета телекоммуникаций имени проф. М.А. Бонч-Бруевича

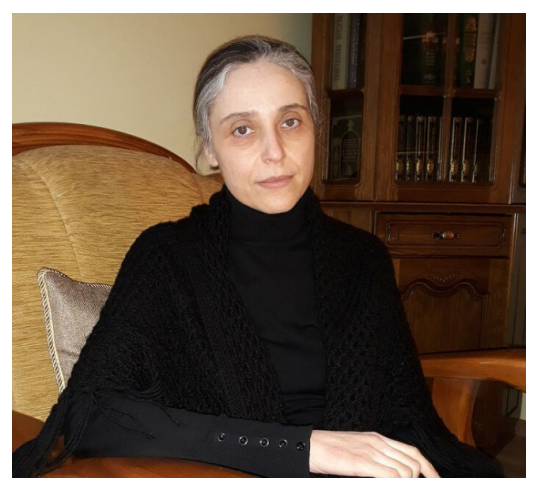

\section{Дегтярников Вячеслав}

Валентинович,

член правления Союза журналистов Пермского края

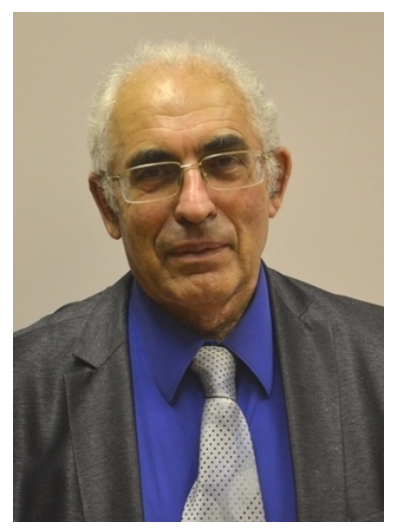




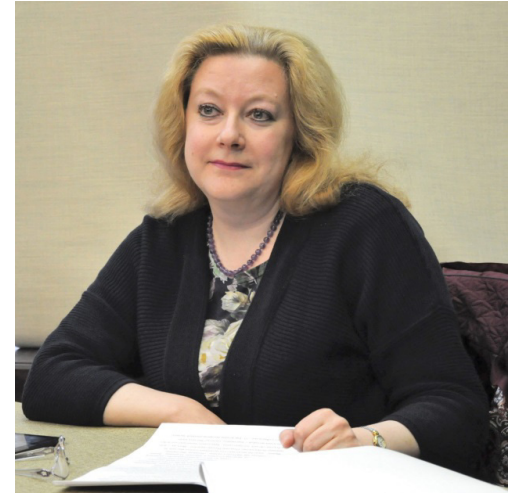

Колдушко Анна Анатольевна, кандидат исторических наук, доцент Пермского национального исследовательского политехнического университета

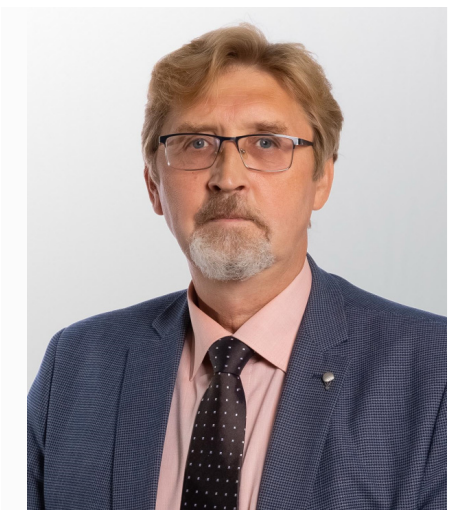

Кантор Юлия Зораховна, доктор исторических наук, главный научный сотрудник Санкт-Петербургского института истории РАН, профессор Российского государственного педагогического университета им. А.И. Герцена

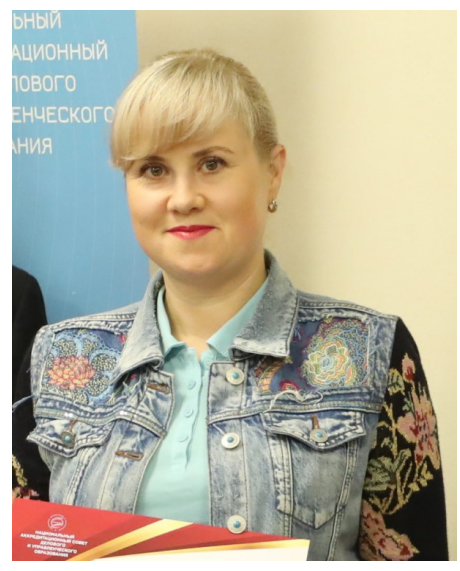

\section{Нечаев Михаил Геннадьевич,} кандидат исторических наук, главный научный сотрудник Музея-заповедника «Пермь-36», доцент Пермского национального исследовательского политехнического университета 


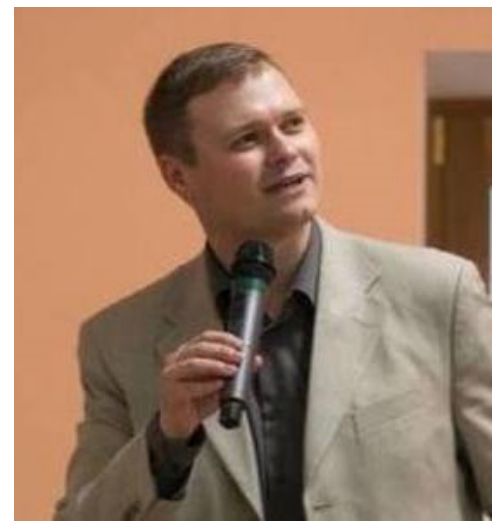

\section{Тихонов Виталий Витальевич,} доктор исторических наук, ведущий научный сотрудник Института российской истории РАН, профессор Российского государственного гуманитарного университета

Шевырин Сергей Андреевич, кандидат исторических наук, заведующий научно-методическим отделом Музея-заповедника «Пермь-36», доцент Пермского государственного гуманитарнопедагогического университета

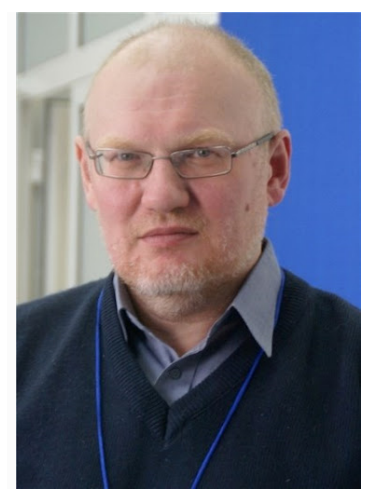

